\title{
DETERMINANTS OF TRANSACTION COSTS IN CONSTRUCTION PROJECTS
}

\author{
Huimin $\mathrm{LI}^{\mathrm{a}}$, David ARDITI ${ }^{\mathrm{b}}$, Zhuofu WANG ${ }^{\mathrm{c}}$ \\ ${ }^{a}$ Department of Construction Engineering and Management, North China University of Water Resources \\ and Electric Power, 450011 Zhengzhou, China \\ ${ }^{b}$ Department of Civil, Architectural and Environmental Engineering, Illinois Institute of Technology, \\ Chicago, IL 60616, USA \\ cDepartment of Construction Engineering Management, Hohai University, 210098 Nanjing, China
}

Received 05 Sep 2012; accepted 13 Mar 2013

\begin{abstract}
Transaction costs occur when a good or service is transferred across a technologically separable interface, and include the costs of drafting, negotiating and enforcing an agreement, and also the costs of governance and bonding to secure commitments. In the complex and high risk environment of a construction project, questionable decisions can be made in the planning and design phase, and disagreements, conflicts, disputes, change orders, and claims can occur in the construction phase. These problems contribute to an increase in transaction costs. Transaction costs at the pre-contract phase of a project are different from the transaction costs at the post-contract phase. However, there is no consensus on a standard definition of transaction costs in construction projects. In this study, a detailed literature review focusing on transaction costs in construction project management is presented. The factors that affect transaction costs are identified and categorized under the headings of the owner's and contractor's roles in the transaction, project management efficiency, and the characteristics of the transaction environment.
\end{abstract}

Keywords: construction project, transaction costs, construction management, transaction cost economics.

\section{Introduction}

The actual cost of a construction project does not consist of only the production cost. The costs of preparing a biding document, estimating, drawing up a contract, administering the contract, and dealing with any deviations from contract conditions are also important. These costs are known as transaction costs in the study of economic organizations. Even though few early researchers like Coase (1937) consider costs that are internal to the organization as well as costs that involve exchanges with external organizations, most researchers, especially in the construction field, consider transaction costs to be mainly composed of external costs.

The transaction paradigm has indeed received considerable attention by academics and has been applied to a variety of construction-related topics including project organization and governance (Piertoforte 1997; Turner, Keegan 2001; Winch 2001; Müller, Turner 2005; Jobin 2008); construction market and subcontracting (Eccles 1981; Gunnarson, Levitt 1982; Reve, Levitt 1984; Winch 1989; Constantino et al. 2001; Bremer, Kok 2000; Miller et al. 2002; Lai 2000); project delivery systems (Lynch 1996; Whittington 2008); construction contracts (Brokmann 2001; Turner, Simister 2001; Bajari, Tadelis
2001); and the measurement of transaction costs (Antinori, Sathaye 2007; Dudkin, Välilä 2005; Ho, Tsui 2009; Soliño, Gago de Santos 2009; Farajian 2010).

On closer examination of this literature, it is observed that there is a lack of standard definition of transaction costs within and across research disciplines. While Williamson (1985) defines transaction costs to include the costs of drafting, negotiating and enforcing an agreement, and also the costs of governance and bonding to secure commitments, Rahman and Kumaraswamy (2002) claim that transaction costs also include costs associated with breaches of contractual promises, and Joskow (1985) adds costs of acquiring and processing information, legal costs, organizational costs, and costs associated with inefficient pricing and production behavior. The concept of transaction cost is not universally accepted by all participants in the construction industry and has not received much recognition by modern practice.

The objective of the study is to identify the determinants of transaction costs borne by the owner in a construction project. In this study, it is postulated that transaction costs include costs incurred by a firm while transacting with an outside organization (i.e. excluding internal transaction costs), and that the factors that affect transaction costs

Corresponding author: David Arditi

E-mail: arditi@iit.edu 
can be categorized under one of the following headings: (1) the role of the owner; (2) the role of the contractor; (3) project management efficiency; and (4) the transaction environment. Transaction costs include pre-contract and post-contract transaction costs. An attempt is made in this paper to discuss the factors that belong to each and every one of these headings in both the pre- and post-contract phases of a construction project by drawing heavily on published research on a wide spectrum of related issues.

\section{Transaction costs in construction projects}

There have been only a few studies (e.g. Soliño, Gago de Santos 2009; Dudkin, Välilä 2005; Farajian 2010) mainly in Europe attempting to quantify transaction costs in construction projects, but only for PPP projects. Most other research is confined only to procurement-phase costs of bidding and contract negotiation, excluding costs related to contract monitoring and renegotiation in the construction and operational phases. Actually, the transaction costs in the construction phase may be much higher than the transaction costs in the procurement phase (Turner, Simister 2001; Hughes et al. 2006; Whittington 2008; Lingard et al. 1998). So there appears to be a need in the construction industry to define transaction costs in a way that covers not only the pre-contract phase but also the construction phase of a project.

\subsection{Pre-contract transaction costs}

Pre-contract transaction costs are incurred before a transaction takes place. They include the costs incurred in drafting and negotiating agreements and vary with the design of the good or service to be provided. In this study, the pre-contract transaction costs are defined as the transaction costs borne by the owner before the construction contract is signed. At the pre-contract stage, Soliño and Gago de Santos (2009) try to distinguish between external costs (such as technical, legal and financial advice) and in-house costs such as project preparation costs. Soliño and Gago de Santos's (2009) pre-contract transaction costs include the costs of environmental impact assessment, feasibility study, preliminary design, and bidding including tender documentation preparation and negotiation. Soliño and Gago de Santos (2009) basically agree with Whittington's (2008) characterization. Whittington (2008) finds in six case studies that pre-contract transaction costs in the design-bid-build project delivery system range from $0.4 \%$ to $8.8 \%$ (average $2.6 \%$ ) of the value of the contract; the range for the design/build project delivery system is 0 to $5.7 \%$ (average $2.2 \%$ ). Based on data collected from PPP projects financed by the European Investment Bank, Dudkin and Välilä (2005) conclude that transaction costs in the pre-contract phase of infrastructure projects, is about $2-3 \%$ of the contract value on average.

Based on a survey of the literature, pre-contract transaction costs include the cost of market research, the cost of exploring financing opportunities, the cost of conducting a feasibility study, the cost of biding/negotiation, and the cost of day-to-day pre-contract project management.

\subsection{Post-contract transaction costs}

Post-contract transaction costs include the costs incurred after the contract has been signed but before the entire transaction has been completed. Post-contract transaction costs include the "setup and running costs of the governance structure to which monitoring is assigned and to which disputes are referred and settled: the maladaptation costs that are incurred; the haggling costs that attend adjustments (or the lack thereof); and the bonding costs of effecting secure (credible) commitments" (Williamson 1985).

Post-contract transaction costs arising from disputes and litigation could be high. Conflict and disputes in the construction industries of many countries (including Australia, USA, the UK, and Hong Kong) inflict a high cost to the industry both in terms of direct costs (lawyers, claims consultants, management time, delays to project completions) and indirect costs (degeneration of working relationships, consequences of mistrust between participants and lack of teamwork) (Yates 1999). Whittington (2008) finds in six case studies that the post-contract transaction costs for the design-bid-build project delivery system range between $8.9 \%$ and $14.7 \%$ (average $12.6 \%$ ) of the contract value; the range for the design/build project delivery system is $3.4 \%$ to $14.3 \%$ (average $9.5 \%$ ).

Based on a survey of the literature, post-contract transaction costs include the cost of day-to-day contract administration, the cost of administering claims and change orders, the cost of dispute resolution, and incentive payments.

\section{Determinants of transaction costs}

The transaction costs of any act of market exchange will depend on the interplay between different sets of human factors and environmental factors (Greenwood, Yates 2007). In a construction project the contractual problems include claims, change orders, and disputes. As Molenaar et al. (2000) suggest the factors that influence disputes include: (1) people issues; (2) process issues; and (3) project issues. People issues involve organizations, relationships, roles, responsibilities, and expectations that affect these people. Process issues involve the manner in which the contract and construction are carried out. Project issues include those characteristics that define the technical nature of the work. On the other hand, Molenaar et al. (2000) argue that only three factors to have direct influence on dispute potential: owner management ability, contractor management ability, and project complexity.

According to transaction cost economics (TCE), it is the inter-relationship between human and environmental factors that should ideally determine the eventual nature and governance structure of the transaction (Greenwood, Yates 2007). The human factors are related to the owner's and contractor's behaviors. The environments factors involve the transaction environments and mechanism and project management issues. Also, contractual 
incompleteness is the key to opportunism. If there were no gaps in contract documentation and no subsequent changes in client requirements and design, there would be no requirement for post-contract "adjustments" and consequently no opportunity for the contractor to behave opportunistically (Yates, Hardcastle 2002). The main factors that give rise to contractual incompleteness are uncertainty, fuelled by the inherent complexity of the construction process, and the bounded rationality of the participants. It follows that an important factor that affects transaction costs is the extent to which plans and specification are complete. In this study, the factors that affect transaction costs are extracted from the literature and are categorized under the headings of the role of the owner, the role of the contractor, project management efficiency and transaction environment (Fig.).

\subsection{The role of the owner}

Walker (1995) considered the influence of the owner and of the owner's representative as a significant factor in construction schedule performance. Owner-related factors include experience, knowledge of construction project organization, financial stability, confidence in the project team, familiarity with construction methods, clarity of project scope, attitude toward risk, and competence in project management (Chan, Kumaraswamy 1997; Songer, Molenaar 1997; Dissanayaka, Kumaraswamy 1999). The role of the owner can be measured by the following indicators.

Change orders are likely to be numerous if the client's requirements are not clearly specified in the contract.
Onyango (1993) found that one of the largest contributors to claims was post contract changes by owners. Chan and Kumaraswamy (1997) also revealed that the common causes of delay included owner-initiated variations. The prospect of many change orders is likely to increase the uncertainty in the owner's behavior. The preventive measures to reduce the frequency and magnitude of change orders and hence reduce transaction costs are discussed by Gunhan et al. (2007). This indicator can be measured by the frequency and magnitude of change orders.

Relationship with other parties focuses on whether the owner has a relationship with designers, suppliers and government agencies that enhances the cooperation between the parties, reduces disagreements, and facilitates the resolution of conflicts. This kind of stability in the owner's relationships reduces the likelihood of litigation (Arditi, Pulket 2010) and is therefore likely to reduce transaction costs primarily in terms of legal fees, hence making the frequency and severity of conflicts a good yardstick for measuring this indicator.

Experience in similar type projects is highly related to the effectiveness of organizational learning. Experiences have value only if the lessons learned from completed similar type projects are kept in the organizational memory and used in future projects (Kululanga, McCaffer 2001). Experience in similar type projects is likely to generate fewer requests for information on the part of the contractor (Arditi et al. 2010), and hence reduce transaction costs.

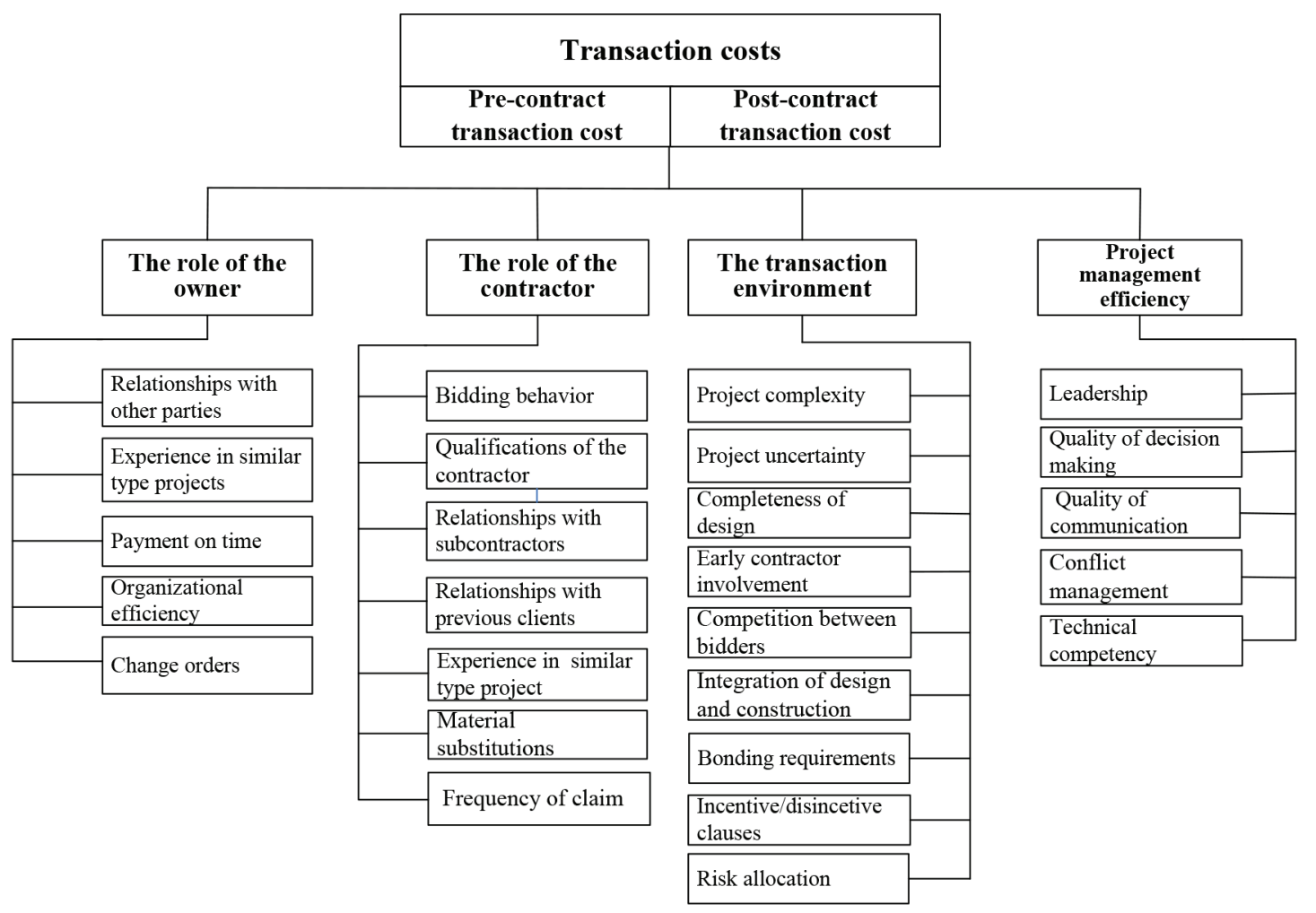

Fig. Determinants of transaction costs in construction projects 
Payment on time concerns the timeliness of payments by the owner. A contractor who consistently receives delayed payments is likely to borrow money and incur finance costs. Given the commonly used "paid when paid" clauses in subcontracts in the U.S., when the contractor's payment is delayed by the owner, subcontractors' payments are delayed by the contractor, leading to friction not only between the owner and the contractor, but also between the contractor and subcontractors (Arditi, Chotibhongs 2005). Good relationships characterized by timely payments on the part of the owner are conducive to fewer claims on the part of the contractor, the absence of legal disputes (Ozorhon et al. 2010), and hence a reduction in transaction costs.

Organizational efficiency involves the ability of a firm to produce maximum output given a set of inputs or to minimize input given a set of required outputs. Organizations try to combine inputs in their cost minimizing proportions, and aim to attain a cost minimizing scale of operation (Mosheim 2002). To be effective, organizations need capabilities relevant to their missions and they must manage those capabilities efficiently. A stable and efficient organization is likely to reduce transaction costs. Concerning the assessment of organizational efficiency, Kaplan and Norton's (1992) Balanced Scorecard Egan's (1998) ten high-level key performance indicators stand out as the most prominent performance measurement models as they considers non-financial as well as financial measures.

If the owner issues a large number of change orders, has strained relationships with other parties (i.e. arbitrated or litigated cases), has little or no experience with similar projects, is typically delayed in appropriating the funds necessary to pay the contractor, and displays organizational inefficiency, then the role of the owner affects transaction costs negatively (i.e. transaction costs will be higher). On the other hand, if the owner issues only few change orders, has smooth relationships with other parties, has had similar projects built in the past, typically pays contractors on time, and has an efficient organization, then the owner affects transaction costs positively (i.e. transaction costs will be lower). Given the owner's performance in these five indicators, different combinations of performance define the role of the owner.

\subsection{The role of the contractor}

Since a contract cannot cover all possible contingencies, the contractor may refuse to rectify defects found in the course of the project, may ask for additional payment due to inflation or other cost overruns, may threaten to deliberately file for bankruptcy, may fall behind schedule, and may either refuse to speed up or may demand extra payment due to the higher costs of overtime, and may pick out design errors and charge unreasonable rates for correcting them (Chang, Ive 2007). The predictability of the contractor's behavior can be measured by the following indicators.
Bidding behavior refers to the bidding behavior of a contractor relative to unbalanced pricing, claims games, and collusion. Unbalanced bids constitute a serious problem for construction owners. The most common way to mathematically unbalance a bid is frontloading where a bidder overstates the unit price of line items scheduled to be performed early in the project and understates the unit price of line items performed later. A bidder can also overstate the unit price of a line item whose quantity was somehow underrated by the engineer. In competitive bidding, awarding a contract to an unbalanced bid may cause the owner's overall project cost to get higher, but it is hard to detect unbalancing (Arditi, Chotibhongs 2009) and in some cases, it generates contentious change orders (Manzo 1997). In times of high competition, some contractors play "claims games" by bidding below cost, and file a large number of claims during construction to recuperate the loss they incurred by bidding low. Collusion is an agreement among a group of firms whereby a bidder is allowed by the other bidders in the group to win a particular bid and obtain the greatest possible benefit from it (Chotibhongs, Arditi 2012). If all firms in the group follow the agreement, construction owners will face higher prices, giving the group members profits above the normal competitive level (Bajari, Summers 2002). Collusive bids are difficult to detect as the process of detection requires expert knowledge. The failure to detect unbalanced bids, contractors who bid unreasonably low, and collusive bids are likely to cost the owner both in terms of transaction costs and production costs (Arditi, Chotibhongs 2009; Chotibhongs, Arditi 2012). A contractor's track record in past bidding should be a good measure of this indicator.

Qualifications of the contractor refers to how cognizant the owner is of the contractor's qualifications at the time the contract is signed. It may sometimes be difficult to judge if the potential contractor is qualified to do the job, and in such circumstances, owners require that the contract be bonded by a third party. If the owner is not informed about the potential contractor's capabilities, the owner may face higher transaction costs due to bonding costs, and the contractor's likely deficiencies relative to the contractor's ability to schedule, coordinate, and control the work. Bonding requirements set by an owner largely reflect a measure of this indicator.

Relationships with subcontractors concerns the quality and strength of the relationships between a general contractor and its subcontractors. As a general contractor and its subcontractors cooperate over the years, the relationships take the form of "relational" contracting (Constantino et al. 2001). Subcontractors typically continue to work with those general contractors that have treated them well in the past. General contractors that do not treat their subcontractors well may not receive bids from them in the future or the subcontractors may decide to raise their bids when they are dealing with general contractors that do not treat them well (Currie et al. 1991). Proctor (1996) 
emphasizes the importance of developing a spirit of trust between general contractors and subcontractors which requires a long-standing practice of fair dealing between parties: consideration, communication, cooperation, and timely compensation. Maintaining relationships of high quality with subcontractors is positively and strongly associated with general contractors' economic performance (Kale, Arditi 2001), and the transaction costs incurred by the owner. The degree of partnering between a contractor and subcontractors can indicate the quality of these relationships.

Experience in similar type projects involves lessons learned from completed projects (Kululanga, McCaffer 2001). A company may enjoy a good reputation if previous projects have been completed on schedule, within budget, in good quality and with minimal conflict (Molenaar et al. 2000).

Relationships with previous owners concern the traditional rivalry between owners and contractors. Even though the importance of cooperation and trust between owners and contractors has been understood somewhat well, a strong relationship between owners and contractors is still difficult to achieve (Bresnen, Marshall 2000). In this sense, owner satisfaction comes into question. In order to satisfy owners' requirements, contractors should recognize the owners' basic expectations relative to cost, time, and quality (Ahmed, Kangari 1995). A smooth relationship is expected to lower transaction costs. The references provided by past owners can measure this indicator.

Material substitution refers to the replacement of one type of material for another. Closed specifications do not allow for substitution with a similar product. Since there is a suggestion of discrimination when only one supply source can be used, closed specifications are not common in public contracts. Closed specifications tend to reduce competitiveness among would-be suppliers. Open specifications allow substitutions after approval by the design professional or owner. As expected, the proposed substitute must meet the same quality and performance standards of the specified proprietary product. In open specifications, there is an opportunity for the contractor to ask more money due to the fluctuations in prices and uncertainty in the supply of the material. Frequent substitutions increase transaction costs. This indicator can be assessed by the number of material substitution requests filed by the contractor.

Frequency of claims is related to the contractor's policy relative to contract administration. Construction claims usually arise as assertions for extra money or time. The filing of a claim by a contractor, the evaluation of the claim by the owner, the resolution of the possible disagreements between the owner and the contractor generate substantial transaction costs. Some construction claims are unavoidable and in fact necessary, to contractually accommodate unforeseen changes in project conditions or unavoidable changes in owner priorities. While such claims may be settled amicably, some can degenerate into unnecessary conflicts and disputes (Kumaraswamy 1997), and in turn, increase transaction costs. The number of claims filed by the contractor determines how much this indicator contributes to transaction costs.

If the contractor displays ethical and lawful bidding behavior, is well qualified to do the job, has harmonious relationships with subcontractors, has constructed similar projects in the past, has had smooth relationships with previous owners, does not often file material substitution requests, and does not often file claims, then the contractor's impact on transaction costs is limited (i.e. transaction costs are low). Transaction costs are expected to be higher or lower depending of the role of the contractor's relative to these indicators.

\subsection{Project management efficiency}

An effective project team can minimize the effect of large complex problems, while an ineffective one, may allow small problems to grow into larger issues. Although cooperative behavior is essential for solving complex problems, it is not sufficient - the project organization requires agreement on project goals, effective decisionmaking processes, and problem solving and negotiation skills (Mitropoulos, Howell 2001). The effectiveness of the project management functions also concerns planning, coordination, monitoring, and controlling, which partly determine the transaction costs of a construction project. It is anticipated that the relative contributions of capability and managerial efficiency are significant factors in organizational resource allocation decisions (Lewis et al. 2009). According to the definition of transaction costs in this study, the costs of day-to-day contract administration, including the administration of claims and change orders, and the resolution of disputes depend largely on project management efficiency. Project management efficiency can be measured by the following indicators.

Leadership is the key to building management capability. Leadership involves developing and communicating mission, vision, and values to the members of an organization. A successful leadership is expected to create an environment for empowerment, innovation, learning, and support (Shirazi et al. 1996). Leaders have a project vision and know how to align people with their goals. They provide the structure, as well as motivation, to tune team performance and inspire their team to take cooperative action and to achieve project objectives, in turn reducing transaction costs (De Meyer 2010). A project manager who enables teams to work together can deliver results faster, eliminates disputes, and reduces transaction costs. Influencing others, harnessing the social and emotional potential of the team members, and inspiring a diverse team to work together are all critical competencies for project managers. The project manager must continuously develop effective leadership skills and employ them as needed during the project cycle. The visible expression of leadership skills for the project 
team and stakeholders is via leadership behaviors. A project manager's leadership skills can be assessed by how the project manager defines roles and responsibilities, establishes trust, facilitates support, and manages outcomes (Anantatmula 2010).

Quality of decision-making is related to project managers dealing with uncertainty, complexity, multiple objectives, and multiple stakeholders. Project managers should never make decisions based on gut instinct, which tends to be biased. Rather, they should follow a decision process that ensures decisions remain consistent among similar projects and all business situations are deeply analyzed and assessed before work begins. Decisions should also be continually evaluated and refined through the course of the project as needed (Virine, Trumper 2008). Decisions dictate the flow of the project, as well as the role each team member plays. Transaction costs are inevitably incurred in the decision making process but making sound decision reduces the amount of time spent on unexpected problems, minimizes disagreements, and helps keeping a project on schedule and within budget, hence reducing transaction costs. In general, the quality of decision-making can be assessed by evaluating the decisionmaking process or the outcome of the decision (Keren, Bruin 2003).

Quality of communication has been identified as a factor that affects the occurrence of disputes (Kumaraswamy 1997), and hence as a determinant of transaction costs. Simply improving communication practices by improving information flow will not reduce per se the incidence of disputes in construction (Love et al. 2009). Fundamentally, work processes, policies, and procedures as well as behaviors need to change in tandem if disputes are to be reduced in construction (Love et al. 2009). Effective communication between the participants is important for good relations between the parties. Communication allows the parties to understand the goals of the project organization, and the roles and responsibilities of all the actors. It also helps with the sharing and dissemination of individual experiences. Project management often involves presiding over work teams that may not even reside in the same country. At the start of each project, the project manager must determine how frequently, and via what medium, team members will be expected to communicate with one another. Effective and efficient communication will ensure that all team members are aware of decisions as soon as they are made, leaving no room for uncertainty in terms of individual responsibilities and goals, hence reducing transaction costs (Silva, Ratnadiwakara 2008). Quality of communication can be assessed by analyzing the number and content of emails, text messages, and telephone calls between the parties or by using specialized project management software such as Autodesk Construct ware or Primavera Contract Management.

Conflict management involves the resolution of serious disagreements and arguments about something important and also of serious differences between two or more beliefs, ideas or interests. Since conflict is inevitable in human relationships (Rhys 1994), it is predictably preponderant in environments where human relationships proliferate, as in construction projects. Conflict management has been said to be a major component in construction project management (Gardiner, Simmons 1995). The potentially unpleasant consequences of conflict can lead to frequently filed claim that sometimes end up in disputes, which in turn reduce project management efficiency and generate higher transaction costs. For example, Jergeas and Hartman (1994) noted many avoidable claims on which valuable resources are wasted. Avoiding disputes is a logical response to the high transaction costs of resolving disputes that have affected construction industries in most countries (Kumaraswamy 1997). A company's conflict management capabilities can be assessed by monitoring the conflict resolution methods specified in the contracts.

Technical competency concerns the extent of technical knowhow available in the company that is necessary to undertake specific projects and the number and type of machinery and equipment owned by the company that are necessary for the physical realization of construction projects (Isik et al. 2010). According to Warszawski (1996), a company's technical competency can be assessed by analyzing the company's preferred construction methods, the experience of its technical staff, the productivity and speed of its construction activities, and the quality of the company's output. The existence of technical competency, i.e. appropriate qualifications and experience is conducive to speedy decisions, smooth operations, few reworks, and easy communication, all of which contribute to lower transaction costs (Carey et al. 2006). It is possible to assess the technical competency of a project team by following the guidelines that are routinely used in the qualification process that is an integral part of the bidding process.

Transaction costs are expected to be higher if project management efficiency is low, i.e. if leadership is lacking in the project team, decision-making is slow and inefficient, communications are poor, no routines exist for efficient conflict management, and technical competence is lacking in the project team. The project management team's different performances in different indicators may affect transaction costs accordingly. One should strive for excellent performance in all indicators for lower transaction costs.

\subsection{The transaction environment}

Inappropriately defined project scope may increase the number of disagreements and disputes during the project (Diekmann, Girard 1995). It is widely accepted that a construction project is subject to more risks than other business activities because of its complexity (Shen et al. 2001). Technical plans/specifications should be subject to a complete review and be complete and clear 
(Diekmann, Girard 1995). Dealing appropriately with uncertainty in transactions is an essential success factor that can avoid a great deal of trouble and conflict in the future. Since there are many potential problems in construction projects, the contract between the owner and the contractor should define the rights and responsibilities of each party clearly. But the contract cannot predict all possible problem situations. Differences may exist in the parties' perception of risk allocation (Mitropoulos, Howell 2001). A study of contract clauses found that there are significant disparities among owners and contractors with respect to the perception of risk allocation of contract clauses (Ibbs, Ashley 1987). In practice, however, costs of identifying contingencies and devising responses increase rapidly in complex or uncertain environments (usually the situation with construction contracts), placing economic limits on agents' abilities to draft and implement elaborate contractual agreements (Walker, Pryke 2009). So there is a tradeoff for the owner between the degree of contractual completeness and marginal costs and the benefits of contractual completeness. The transaction environment can be measured by the following indicators.

Project complexity impacts the uncertainty in the transaction environment. The specific responses that different parties in construction manifest depend on the certainty of the environment. This environmental instability increases transaction costs (Farajian 2010).

Project uncertainty is the difference between the amount of information required to do the task and the amount of information already processed by the organization (Galbraith 1973). The amount of information needed depends on (1) task complexity (the number of different factors that have to be coordinated) and (2) performance requirements (such as time or budget constraints). The amount of information possessed depends on the effectiveness of planning - that is, the collection and interpretation of information before the task. Uncertainty means that every detail of a project cannot be planned before work begins (Laufer 1991). When project uncertainty is high, initial drawings and specifications are likely to Change, and the project members will have to solve many problems during construction. The technical complexity of the project expressed in terms of impact factors such as weather and soil conditions, also affects contractual uncertainty. Uncertainty in material prices is another problem, especially if the contract has a long life cycle.

Completeness of design is a measure of how well the owner or A/E have defined, documented and specified the project. Unlike many other industries, construction is a complex blend of disparate needs, skills, and techniques that are difficult to coordinate. It is widely accepted that a construction project is subject to more risks than other business activities because of its complexity (Shen et al. 2001). Inappropriately defined project scope may increase the number of change orders, disagreements and disputes during the project (Diekmann, Girard 1995), hence increasing transaction costs.

Early contractor involvement is bound to have an effect on the many complex and uncertain processes owners face at the beginning of a construction project. Such a cooperative route seeks to obtain long-term gains through increased cooperation and integration of design and construction. It is also important to establish a trust-based cooperative relationship by facilitating contractors' contributions in the design stage (Korczynski 1996; Eriksson, Pesämaa 2007). The collateral effect of early contractor involvement in the design phase is a reduction in transaction costs as constructability problems are minimized in the construction phase.

Competition between bidders is the basic principle of project procurement. The absence of competition is associated with relatively low costs of bidding and contract negotiation (Dudkin, Välilä 2005). This is due to less work for the owner in terms of prescreening and proposal evaluation. On the other hand, it is likely that the absence of competition also increases costs as the lack of competition is likely to result in higher bids and in a higher probability of contract renegotiation during construction. Farajian (2010) also agrees with the idea that a lesser amount of competition can generate relatively low transaction costs during the project initiation and procurement phases, but it is likely that total project costs will be higher due to the weaker competitive procurement process.

Integration of design and construction capitalizes on the close relationship between design and construction. These processes can best be viewed as an integrated system. Broadly speaking, design is a process of creating the description of a new facility, usually represented by detailed plans and specifications; construction is the implementation of a design envisioned by architects and engineers. In both design and construction, numerous operational tasks must be performed with a variety of precedence and other relationships among the different tasks. Improved integration, collaboration and communication in the interface between design and construction reduces transaction costs (Vrijhoef, Ridder 2007), and can be achieved by project delivery systems such a design/build or integrated project delivery as opposed to the traditional design-bid-build system.

Bonding requirements refers to third party guarantees on contractor performance. Suppose that the owner and the contractor initially enter into a legal agreement without any financial protection. Since a contract cannot cover all possible contingencies, some owners will find that their vulnerability may be exploitable under certain circumstances. The use of financial instruments such as surety bonds is commonplace to protect owner interests (Hughes et al. 1998; Russell 2000). Although the bonding fee is paid by the contractor, this is reflected in the contractor's overhead, which in turn is recovered from the owner. On the other hand, bonding requirements would 
discourage any opportunistic behavior on the part of the contractor (Mysen et al. 2011), hence reducing transaction costs.

Incentive/disincentive clauses are important in construction contracts to encourage contractors to perform on schedule and /or within budget. Both parties to the contract can reap the benefits of enhanced performance (Egan 1998; Bayliss et al. 2004; Love et al. 2004). The aim of this arrangement is to motivate the contractor and owner to work together to minimize project duration and/ or actual costs; the contractor is able to maximize profits by capturing incentives, and the owner is motivated to minimize the total project duration and/or cost (Broome, Perry 2002).

Fair risk allocation refers to the proper allocation of risks between the owner and the contractor. While some risks can be retained by the owner, some risks are transferred to the contractor and third parties like surety companies. If risks are allocated to the party that can best handle it, the integrity and acceptance of the contract are improved and the relationships between the parties are impacted positively. However, whenever risks are transferred to the contractor, contractors usually respond to these risks by increasing their contingency and markup, which ultimately increases the contract price to the owner (El-Sayegh 2008). Fair risk allocation reduces conflicts and disputes, and consequently reduces transaction costs.

A transaction environment that is defined by project complexity, uncertainty in schedule and budget, incomplete design, delayed contractor involvement, limited competition between bidders, disconnected design and construction activities, excessive bonding requirements, no contract incentives/disincentives, and unfair risk allocation in the contract is likely to generate higher transaction costs. While some of the indicators can be easily controlled, some are difficult to change due to established habits, rules, regulations, and laws. One should nevertheless strive to keep transaction costs down by controlling as many of these indicators as possible.

\section{Conclusions}

The construction project is performed in a complex environment where one should distinguish between production and transaction costs. In such an environment, questionable decisions can be made that can impact transaction costs both in the pre-contract and post-contract phases. However, there is inconsistency in defining "transaction costs" (Farajian 2010). In this study, only costs incurred while transacting with external organizations are considered, and an attempt is made to identify the factors that affect transaction costs by extracting them from the relevant literature. These factors are categorized under the headings of (1) the role of the owner; (2) the role of the contractor; (3) project management efficiency; and (4) the transaction environment. Significant effort was made to cover much of the literature published about this wide spectrum of issues and to synthesize the various outcomes in order to explain the nature of transaction costs in terms that are acceptable to construction practitioners. The model presented in this paper (Fig.) is a thorough explanation of transaction costs that has so far been missing in the literature. The factors that affect transaction costs in this model finally bring some measure of clarity to the concept of transaction costs in construction projects.

As far as the owner's role in the transaction is concerned, the management of change orders, the owner's relationships with other parties, the owner's experience in similar type projects, making subcontractor payments on time, and organizational efficiency appear to be cited frequently in the literature as affecting transaction costs. As far as the contractor's role in the transaction is concerned, the literature indicates that the following factors may be of importance: bidding behavior, qualifications, experience in similar type projects, relationships with subcontractors and previous owners, material substitutions, and claim strategy. The project management-related factors that affect transaction costs are generally believed to be leadership capabilities, quality of decision-making and communication, conflict management, and technical competency. Finally, the characteristics of the transaction environment also appear to have an impact on the magnitude of transaction costs. These characteristics can be expressed in terms of project complexity, project uncertainty, completeness of design, timing of contractor involvement, competition between bidders, degree of integration of design and construction, bonding requirements, incentive/disincentive clauses, and risk allocation. It is recommended that an empirical study be conducted to confirm/refute the importance of the factors presented in this paper.

\section{References}

Ahmed, S. M.; Kangari, R. 1995. Analysis of client-satisfaction factors in construction industry, Journal of Management in Engineering ASCE 11(2): 36-44.

http://dx.doi.org/10.1061/(ASCE)0742-597X(1995)11:2(36)

Anantatmula, V. S. 2010. Project manager leadership role in improving project performance, Engineering Management Journal 22(1): 13-22.

Antinori, C.; Sathaye, J. 2007. Assessing transaction costs of project-based greenhouse gas emission trading. Lawrence Berkeley National Laboratory Formal Report LBNL57315.

Arditi, D.; Chotibhongs, R. 2005. Issues in subcontracting practice, Journal of Construction Engineering and Management ASCE 131(8): 866-876.

http://dx.doi.org/10.1061/(ASCE)0733-9364(2005)131:8(866)

Arditi, D.; Chotibhongs, R. 2009. Detection and prevention of unbalanced bids, Construction Management and Economics 27(8): 721-732. http://dx.doi.org/10.1080/01446190903117785

Arditi, D.; Polat, G.; Akin, S. 2010. Lessons learned system in construction management, International Journal of Project Organization and Management 2(1): 61-83. http://dx.doi.org/10.1504/IJPOM.2010.031882 
Arditi, D.; Pulket, T. 2010. Predicting the outcome of construction litigation using an integrated artificial intelligence model, Journal of Computing in Civil Engineering ASCE 24(1): 73-80.

http://dx.doi.org/10.1061/(ASCE)0887-3801(2010)24: $1(73)$

Bajari, P.; Summers, G. 2002. Detecting collusion in procurement auctions, Antitrust Law Journal 70(1): 143-170.

Bajari, P.; Tadelis, S. 2001. Incentives versus transaction costs: a theory of procurement contracts, RAND Journal of Economics 32(3): 387-407. http://dx.doi.org/10.2307/2696361

Bayliss, R.; Cheung, S.; Suen, H.; Wong, S. P. 2004. Effective partnering tools in construction: a case study on MTRC TKE contract in Hong Kong, International Journal of Project Management 22(3): 253-363. http://dx.doi.org/10.1016/S0263-7863(03)00069-3

Bremer, W.; Kok, K. 2000. The Dutch construction industry: a combination of competition and corporatism, Building Research and Information 28(2): 98-108. http://dx.doi.org/10.1080/096132100369000

Bresnen, M.; Marshall, N. 2000. Building partnerships: case studies of client-contractor collaboration in the UK construction industry, Construction Management and Economics 18(7): 819-832. http://dx.doi.org/10.1080/014461900433104

Brokmann, C. 2001. Transaction cost in relationship contracting, AACE International Transactions, 1-7.

Broome, J.; Perry, J. 2002. How practitioners share fractions in target cost contracts, International Journal of Project Management 20(1): 59-66. http://dx.doi.org/10.1016/S0263-7863(00)00035-1

Carey, P.; Subramaniam, N.; Ching, K. C. W. 2006. Internal audit outsourcing in Australia, Accounting and Finance 46(1): 11-30. http://dx.doi.org/10.1111/j.1467-629X.2006.00159.x

Chan, D. W. M.; Kumaraswamy, M. M. 1997. A comparative study of the causes of time and cost overruns in Hong Kong construction projects, International Journal of Project Management 15(1): 55-63. http://dx.doi.org/10.1016/S0263-7863(96)00039-7

Chang, C. Y.; Ive, G. 2007. Reversal of bargaining power in construction projects: meaning, existence and implications, Construction Management and Economics 25(8): 845-855. http://dx.doi.org/10.1080/01446190601164113

Chotibhongs, R.; Arditi, D. 2012. Analysis of collusive bidding behaviour, Construction Management and Economics 30(3): 221-231.

http://dx.doi.org/10.1080/01446193.2012.661443

Coase, R. 1937. The nature of the firm, Economica 4(16): 386-405. http://dx.doi.org/10.1111/j.1468-0335.1937.tb00002.x

Constantino, N.; Pietroforte, R.; Hamill, P. 2001. Subcontracting in commercial and residential construction: an empirical investigation, Construction Management and Economics 19(4): 439-447. http://dx.doi.org/10.1080/01446190010020390

Currie, O. A.; Sweeney, N. J.; Hafer, R. F. 1991. Construction subcontracting: a legal guide for industry professionals. Hoboken: John Wiley \& Sons Inc. 32 p.

De Meyer, A. 2010. Collaborative leadership: new perspectives in leadership development. Working Paper, Cambridge Judge Business School, University of Cambridge.

Diekmann, J. E.; Girard, M. J. 1995. Are contract disputes predictable, Journal of Construction Engineering and Management ASCE 121(4): 355-363.

http://dx.doi.org/10.1061/(ASCE)0733-

9364(1995)121:4(355)
Dissanayaka, S. M.; Kumaraswamy, M. M. 1999. Evaluation of factors affecting time and cost performance in Hong Kong building projects, Engineering, Construction and Architectural Management 6(3): 287-298. http://dx.doi.org/10.1108/eb021119

Dudkin, G.; Välilä, T. 2005. Transaction costs in public-private partnerships: a first look at the evidence. Economic and Financial Report, European Investment Bank.

Eccles, R. G. 1981. The quasi-firm in the construction industry, Journal of Economic Behavior and Organization 2(4): 335-357. http://dx.doi.org/10.1016/0167-2681(81)90013-5

Egan, J. 1998. Rethinking construction. Construction Task Force Report for Department of the Environment, Transport and the Regions, HMSO, London.

El-Sayegh, S. M. 2008. Risk assessment and allocation in the UAE construction industry, International Journal of Project Management 26(4): 431-438. http://dx.doi.org/10.1016/j.ijproman.2007.07.004

Eriksson, P. E.; Pesämaa, O. 2007. Modelling procurement effects on cooperation, Construction Management and Economics, 25(8): 893-901. http://dx.doi.org/10.1080/01446190701468844

Farajian, M. 2010. Transaction cost estimation model for us infrastructure public private partnerships. MS Thesis. University of Maryland, College Park, MD, USA.

Galbraith, J. R. 1973. Designing complex organizations. AddisonBoston: Wesley Longman Publishing Co., Inc. 15 p.

Gardiner, P. D.; Simmons, J. E. L. 1995. Case explorations in construction conflict management, Construction Management and Economics 13(3): 219-234.

http://dx.doi.org/10.1080/01446199500000026

Greenwood, D. J.; Yates, D. J. 2007. The determinants of successful partnering: a transaction cost perspective, Journal of Construction Procurement 12(1): 4-22.

Gunhan, S.; Arditi, D.; Doyle, J. 2007. Avoiding change orders in public school construction, Journal of Professional Issues in Engineering Education and Practice ASCE 133(1): 67-73. http://dx.doi.org/10.1061/(ASCE)10523928(2007)133:1(67)

Gunnarson, S.; Levitt, R. E. 1982. Is a building construction project a hierarchy or a market?, in Proceedings of the Seventh World Congress of Project Management, 12-17 September 1982, Copenhagen, Denmark, 1-9.

Ho, P.; Tsui, C. W. 2009. The transaction costs of public-private partnerships: implications on PPP governance design, in Proceedings of the ASCE LEAD Speciality Conference Global Governance in Project Organizations, 5-7 November 2009, South Lake Tahoe, California, 1-12.

Hughes, W.; Hillebrandt, P.; Murdoch, J. 1998. Financial protection in the UK building industry: bond, retention and guarantees. London: E \& FN Spon. 5 p. http://dx.doi.org/10.4324/9780203478226

Hughes, W.; Hillebrandt, P.; Greenwood, D.; Kwawu, W. 2006. Procurement in the construction industry: the impact and cost of alternative market and supply processes. London and New York: Taylor and Francis. 17 p.

Ibbs, C. W.; Ashley, D. B. 1987. Impact of construction contract clauses, Journal of Construction Engineering and Management ASCE 113(3): 501-517. http://dx.doi. org/10.1061/(ASCE)0733-9364(1987)113:3(501)

Isik, Z.; Arditi, D.; Dilmen, I.; Birgonul, M. T. 2010. The role of exogenous factors in the strategic performance of construction companies, Engineering, Construction and Architectural Management 17(2): 119-134. http://dx.doi.org/10.1108/09699981011024650

Jergeas, G. F.; Hartman, F. T. 1994. Contractors' claims avoidance, Journal of Construction Engineering and Management ASCE 120(3): 553-360. http://dx.doi.org/10.1061/ (ASCE)0733-9364(1994)120:3(553) 
Jobin, D. 2008. A transaction cost-based approach to partnership performance evaluation, Evaluation 14(4): 437-456. http://dx.doi.org/10.1177/1356389008095487

Joskow, P. L. 1985. Vertical integration and long-term contracts: the case of coal-burning electric generating plants, Journal of Law, Economics, and Organization 1(1): 33-80.

Kale, S.; Arditi, D. 2001.General contractors' relationships with subcontractors: a strategic asset, Construction Management and Economics 19(5): 541-549. http://dx.doi.org/10.1080/01446190110049839

Kaplan, R. S.; Norton, D. P. 1992. The balanced scorecard measures that drive performance, Harvard Business Review 70(1): 71-79.

Keren, G.; Bruin, W. B. 2003. On the assessment of decision quality: considerations regarding utility, conflict and accountability, in Hardman, D.; Macchi, L. (Eds.). Psychological perspectives on reasoning, judgment and decision making. Hoboken: John Wiley \& Sons, 347-363.

Korczynski, M. 1996. The low-trust route to economic development: inter-firm relations in the UK engineering construction industry in the 1980s and 1990s, Journal of Management Studies 33(6): 787-808. http://dx.doi.org/10.1111/j.1467-6486.1996.tb00172.x

Kululanga, G. K.; McCaffer, R. 2001. Measuring knowledge management for construction organizations, Engineering, Construction and Architectural Management 8(5/6): 346-354. http://dx.doi.org/10.1108/eb021195

Kumaraswamy, M. M. 1997. Conflicts, claims and disputes in construction, Engineering, Construction and Architectural Management 4(2): 95-111. http://dx.doi.org/10.1108/eb021042

Lai, L. W. C. 2000. The Coasian market-firm dichotomy and subcontracting in the construction industry, Construction Management and Economics 18(3): 355-362. http://dx.doi.org/10.1080/014461900370717

Laufer, A. 1991. Project planning: timing issues and path of progress, Project Management Journal 22(2): 39-45.

Lewis, H. F.; Lock, K. A.; Sexton, T. R. 2009. Organizational capability, efficiency, and effectiveness in Major League Baseball: 1901-2002, European Journal of Operational Research 197(2): 731-740. http://dx.doi.org/10.1016/j.ejor.2008.07.002

Lingard, H.; Hughes, W. P.; Chinyio, E. 1998. The impact of contractor selection method on transaction costs: a review, Journal of Construction Procurement 4(2): 89-102.

Love, P.; Irani, Z.; Edwards, D. 2004. A rework reduction model for construction projects, IEEE Transactions on Engineering Management 51(4): 426-440. http://dx.doi.org/10.1109/TEM.2004.835092

Love, P. E. D.; Edwards, D. J.; Irani, Z.; Walker, D. H. T. 2009. Project pathogens: the anatomy of omission errors in construction and resource engineering projects, IEEE Transactions on Engineering Management 56(3): 425-435. http://dx.doi.org/10.1109/TEM.2008.927774

Lynch, T. D. 1996. A transaction cost framework for evaluating construction project organization. Doctoral Dissertation. Pennsylvania State University, University Park, PA, USA.

Manzo, F. A. 1997. The impact of an unbalanced bid on the change order process, Construction for News 7 (1): 1-8.

Miller, C. J. M.; Packham, G. A.; Thomas, B. C. 2002. Harmonization between main contractors and subcontractors: a prerequisite for lean construction?, Journal of Construction Research 3(1): 67-82. http://dx.doi.org/10.1142/S1609945102000059

Mitropoulos, P.; Howell, G. 2001. Model for understanding, preventing, and resolving project disputes, Journal of Construction Engineering and Management ASCE 127(3): 223-231. http://dx.doi.org/10.1061/(ASCE)07339364(2001)127:3(223)
Molenaar, K. R.; Washington, S.; Diekmann, J. 2000. Structural equation model of construction contract dispute potential, Journal of Construction Engineering and Management ASCE 126(4): 268-277. http://dx.doi.org/10.1061/ (ASCE)0733-9364(2000)126:4(268)

Mosheim, R. 2002. Organizational type and efficiency in the Costa Rican coffee processing sector, Journal of Comparative Economics 30(2): 296-316. http://dx.doi.org/10.1006/jcec.2002.1773

Müller, R.; Turner, J. R. 2005. The impact of principal-agent relationship and contract type on communication between project owner and manager, International Journal of Project Management 23(5): 398-403.

http://dx.doi.org/10.1016/j.ijproman.2005.03.001

Mysen, T.; Svensson, G.; Payan, J. M. 2011. The key role of opportunism in business relationships, Marketing Intelligence and Planning 29(4): 436-449. http://dx.doi.org/10.1108/02634501111138581

Onyango, D. 1993. Reduction in conflicts in construction. MSc Report. Loughborough University of Technology, UK.

Ozorhon, B.; Arditi, D.; Dikmen, I.; Birgonul, M. T. 2010. The performance of international joint ventures in construction, Journal of Management in Engineering ASCE 26(4): 209-222.

http://dx.doi.org/10.1061/(ASCE)ME.1943-5479.0000022

Piertoforte, R. 1997. Communication and governance in the building process, Construction Management and Economics 15 (1): 71-82.

http://dx.doi.org/10.1080/014461997373123

Proctor, J. R. 1996. Golden rule of Contractor-Subcontractor Relations, Practice Periodical on Structural Design and Construction ASCE 1(1): 12-14. http://dx.doi.org/10.1061/(ASCE)1084-0680(1996)1:1(12)

Rahman, M. M.; Kumaraswamy, M. M. 2002. Minimising transaction costs, maximising relational benefits and optimizing risk management - through partnering in Hong Kong projects, International Journal for Construction Marketing 3(2): 51-72.

Reve, T.; Levitt, R. E. 1984. Organization and governance in construction, International Journal of Project Management 2(1): 17-25. http://dx.doi.org/10.1016/0263-7863(84)90054-1

Rhys, J. S. 1994. How constructive is construction law?, Construction Law Journal 10: 28-38.

Russell, J. S. 2000. Surety bonds for construction contracts. Reston: ASCE Press. 227 p. http://dx.doi.org/10.1061/9780784404263

Shen, L. Y.; Wu, G. W. C.; Ng, C. S. K. 2001. Risk assessment for construction joint ventures in China, Journal of Construction Engineering and Management ASCE 127(1): 76-81. http://dx.doi.org/10.1061/(ASCE)07339364(2001)127:1(76)

Shirazi, B.; Langford D.; Rowlinson S. 1996. Organizational structures in the construction industry, Construction Management and Economics 14(3): 199-212. http://dx.doi.org/10.1080/014461996373467

Silva, D. H.; Ratnadiwakara, D. 2008. Using ICT to reduce transaction costs in agriculture through better communication: a case study from Sri Lanka. Working Paper, LIRNEasia, Colombo Sri Lanka.

Soliño, A. S.; Gago de Santos, P. 2009. Transaction costs in PPP transport infrastructure projects. Working paper. European Investment Bank.

Songer, A. D.; Molenaar, K. R. 1997. Project characteristics for successful public-sector design-build, Journal of Construction Engineering and Management ASCE 123(1): 34-40. http://dx.doi.org/10.1061/(ASCE)07339364(1997)123:1(34) 
Turner, J. R.; Keegan, A. 2001. Mechanisms of governance in the project-based organization: roles of the broker and steward, European Management Journal 19(3): 254-267. http://dx.doi.org/10.1016/S0263-2373(01)00022-6

Turner, J. R.; Simister, S. J. 2001. Project contract management and a theory of organization, International Journal of Project Management 19(8): 457-464. http://dx.doi.org/10.1016/S0263-7863(01)00051-5

Virine, L.; Trumper, M. 2008. Project decisions: the art and science. Tysons Corner: Management Concepts. 8 p.

Vrijhoef, R.; Ridder, H. 2007. Supply chain systems engineering in construction. Working paper. Delft University of Technology.

Walker, D. H. T. 1995. The influence of client and project team relationships upon construction time performance, Journal of Construction Procurement 1(1): 4-20.

Walker, F.; Pryke, S. 2009. Role definition and dimensions of incomplete construction contract documents, in Proceedings of RICS COBRA Research Conference, 10-11 September 2009, University of Cape Town, South Africa, 1258-1275.

Warszawski, A. 1996. Strategic planning in construction companies, Journal of Construction Engineering and Management ASCE 122(2): 133-140. http://dx.doi.org/10.1061/ (ASCE)0733-9364(1996)122:2(133)
Whittington, J. M. 2008. The transaction cost economics of highway project delivery: design-build contracting in three states. Doctoral Dissertation. University of California, Berkeley, CA, USA.

Williamson, O. E. 1985. The economic institutions of capitalism: firms, markets, relational contracting. New York: The Free Press. 20 p.

Winch, G. 1989. The construction firm and the construction project: a transaction cost approach, Construction Management and Economics 7(4): 331-345. http://dx.doi.org/10.1080/01446198900000032

Winch, G. M. 2001. Governing the project process: a conceptual framework, Construction Management and Economics 19(8): 799-808. http://dx.doi.org/10.1080/01446190110074264

Yates, D. J.; Hardcastle, C. 2002. The causes of conflict and disputes in construction: a review of current research, Journal of Financial Management of Property and Construction 7(3): 203-214.

Yates, D. J. 1999. Conflict and dispute in the development process: a transaction cost economic perspective. Working paper. Department of Real Estate and Construction, the University of Hong Kong.

Huimin LI. He is a Lecturer in the Department of Construction Engineering and Management at North China University of Water Resources and Electric Power, China. He holds a PhD in Management Science and Engineering and he conducts research and publishes regularly in the area of transaction costs in construction. His interests also include a range of areas within the Construction Management discipline including project delivery systems, procurement processes, risk management and schedule management.

David ARDITI. He is currently Professor of Civil and Architectural Engineering at Illinois Institute of Technology. He is the founder and Director of the Construction Engineering and Management Program since 1981. His area of expertise covers all aspects of construction management, engineering and support. Dr. Arditi and his research associates have published over 250 papers in refereed national and international journals and in peer reviewed conference proceedings. He is an active member of several professional societies, is currently serving on the editorial board of eight journals, and regularly reviews papers and books for several publications.

Zhuofu WANG. He is a Professor in the Department of Construction Engineering and Management at Hohai University, China. He holds a $\mathrm{PhD}$ degree from Hohai University and his research focuses on many areas of construction engineering and management. He has numerous research publications in journals and at conferences on PERT, scheduling risk, bidding mechanisms, incentive mechanisms, project delivery systems, and transaction cost analysis. 